\title{
Gloc-9 as Organic Public Intellectual: Hip and Polished, Raw and Cool
}

\author{
Lara Katrina T.Mendoza
}

This paper will present Aristotle Pollisco-the singer-rapper-songwriter known as Gloc-9—as an organic and a as-yet-unrealised public intellectual. The term "organic" describes Gloc 9's lack of academic or institutional recognition. No academic institutions recognize his level of influence and power. As a public intellectual, however, Gloc-9 enjoys immense popularity with his core fanbase, which is largely made up of listeners from the lower classes.

\begin{abstract}
This paper uses both Antonio Gramsci's definition of the organic public intellectual and Edward Said's claim regarding the exhortation of public intellectuals who exercise their political will in the public sphere. Mikhail Bakhtin's discourse on the carnivalesque will bolster this paper's claim that Gloc- 9 assumes the role of an organic public intellectual through his music. In attempting to confront powerful institutions, Gloc-9 upends the social order through his songs rather than engaging other public intellectuals and scholars in ideological discourse. The paper will closely examine five of Gloc-9's chart-topping songs dealing with poverty, social injustice, gender inequality, and corruption.
\end{abstract}

Keywords: organic public intellectual, rap, hiphop, social awareness, Edward Said, Mikhail Bakhtin

\section{Gloc-9: Mouthpiece of the Oppressed}

Before he was Gloc-9, Aristotle "Aris" Pollisco was born to poor parents in the town of Binangonan, Rizal. For the most part of the 1980-1990, Gloc-9 was a student with the ability to break into flowing, poetic rap that awed his friends as they walked to school. Growing up poor, Gloc-9 finished a college degree in 1994 at Far Eastern University (FEU) and took up nursing at STI (De Veyra \& Sabayton, 2012).

He idolized Francis Magalona (FrancisM) who began as a matinee screen idol and transitioned into a smooth, suave hip-hop artist. In a 2012 interview on "Wasak," Lourd de Veyra praised him: "Hindi lang sing bilis $n g$ Armalite ang kanyang pag-rap, sing tulis din $n g$ taret ang kanyang mga letrang tumatalakay sa mga isyung panlipunan" ["Not only is his rapping as rapid as machine-gun fire, but also his wit is as sharp as a castle turret in tackling pressing social issues"] (De Veyra \& Sabayton, 2012).

Recognized not only as one of the country's foremost rappers for songs he writes and performs with alacrity and fierce, manic joy, Gloc-9 was hailed 
as the mouthpiece of justice against oppression, and adored and respected by legions of music lovers. To coin Noam Chomsky, Gloc-9 dares to speak truth to power. Cliché as this phrase may have come to seem, Gloc-9 is the symbol of the bold, fearless underdog who defies the status quo, delivering scathing critiques against the vanguards of corruption, power-grabbing politicians and self-satisfied elites. It is around the symbol of this defiance that his followers have rallied around.

Gloc's rap is guttural even as it adheres to the smooth contours of Western hip-hop cadences. His social commentary is scathing and unforgiving. It is the ultimate triumph of an exuberant Robin Hood in a society bitterly divided by class, and whose majority remains devastated by poverty.

His songs expose the excesses of the rich and powerful, and hypocrisy and greed reviled. There is no mirth in Gloc-9's social commentary. Gloc-9 is loved not for his ability to make people laugh and forget their worries but for his ability to put into scathing words the resentment and horror that the poor must endure on a daily basis while living alongside the callous, unseeing upper classes in the city's teeming streets.

Writer and scholar Katrina Stuart Santiago (2011) is a self-confessed Gloc-9 fan who admitted that she had practically memorized the songs on Gloc-9's Talumpati [Speech] and Matrikula [Tuition]. In one interview with the rap artist, she combs through the photos of Gloc-9's moments with the rap icon FrancisM:

And then there's Gloc-9. He who seems to be looking in on the nation at the same time that he lives in it, he who on the one hand points a finger and on the other is actually looking at his own reflection. There is an amount of self reflexivity in Gloc-9, and it is revealed not just in the original Pinoy music that he creates, but in the processes of production it involves itself in, including of course living with eyes wide open in a nation that demands it. (Para. 8)

Gloc-9 positions himself as champion of the poor. In his songs, the poor can confront powerful institutions with the truth. They can fight back. In many ways, Gloc-9 is an organic intellectual, an unwitting public intellectual criticizing a system he is not part of and speaking on behalf of a disenfranchised majority.

His music, strident and visceral, mirrors Bakhtin's (1994) assertion that the celebration of the carnivalesque, the upending of a hierarchical society, is a break from the struggles and tedium of a hopeless existence. The fierce, manic joy that underlies his songs are pulsating, straining resentments 
that constantly bubble and seethe underneath the fragile membrane that separates the oppressor from the oppressed.

\section{The Role of the Public Intellectual}

Perhaps one of the most important (if not seminal) works of postcolonial study is Edward Said's (1978) Orientalism. In his introduction, Said describes the way James Arthur Balfour governed Orientals-specifically Egyptiansunder the assumption that they needed regulation and control. ${ }^{1}$

It does not occur to Balfour, however, to let the Egyptian speak for himself, since presumably any Egyptian who would speak out is more likely to be "the agitator [who] wishes to raise difficulties" (Said, 1978, p. 33) than the good native who overlooks the "difficulties" of foreign domination.

While a public intellectual confronts powerful institutions, an organic public intellectual attempts the same without enjoying the validation provided by the academe.

To be considered a public intellectual, according to Edward Said (1978), one must necessarily be an outsider ${ }^{2}$ who must necessarily assume the role of the critic and advocate of the marginalized, the ostracized, and the voiceless. Along with other thinkers in the American public sphere, Said insisted on speaking truth to power.

In an interview from Al Ahram Weekly Online, Noam Chomsky remarks that one cannot truly speak to power unless one is in power himself (Tresilian, 2010). Only people who recognize each other as equals-copowerful or equally powerful-can speak the truth as they see it to each other. In government, cabinet secretaries can speak truth to equally powerful secretaries.

Caroline Sy-Hau (2014) describes the Filipino intellectual and their work as "grappling with ideas, a category that includes, but [they are] not limited to, academics, journalists, and writers" (p. 30).

The difficulty of accepting Karl Marx's economic determinism-the causal relationship between the base (economic structures) and the superstructure (culture) - helped formulate the notion of organic ideologies (Heflin, 2008).

Both Stuart Hall and Antonio Gramsci contested Vladimir Lenin's ${ }^{3}$ notion of vanguardism, ${ }^{4}$ which claims that leading intellectuals must originate from outside the dominated classes for meaningful change to occur (Heflin, 2008). Hall (1986) appropriates Gramsci's notion of the organic intellectual and describes such individuals as having:

[S]pecialized responsibility for the circulation and development of culture and ideology and who either align themselves with the existing dispositions of social 
and intellectual forces ('traditional intellectuals') or align themselves with the emerging popular forces and seek to elaborate new currents of ideas ("organic intellectuals") (p. 433).

Gramsci's (as cited by Olsaretti, 2014) ideas of hegemony were largely informed by Antonio Labriola, who advocated that, "...socio-economic and political emancipation also involved an intellectual and moral reform by the people and that Marxism contained within itself the seeds of this intellectual and moral reform" (p. 341). Gramsci acknowledged that organic intellectuals alone could not effect cultural and structural change. I therefore contend that within Manila's stratified urban setting, the music of artists such as Gloc-9 represent a strident voice from the margins or peripheries that speaks to power by way of addressing the marginalized.

Said (1978) describes himself as one who is neither here nor there, a refugee fleeing from his homeland and yet never quite feeling at home in the United States despite his affiliation with the country's top university. SyHau (2014) highlights Said's experience by describing notions of spatiality as central to allowing Said-both outsider and intellectual-to speak for othered groups. Sy-Hau notes that:

The question of "the personal," that is, the intellectual's own role and position in society-or more accurately, across different societies-is central to the exchange not only between [Reynaldo] Ileto and his interlocutors, but also to Said and his interlocutors. (p. 30).

Rahmin Jahanbegloo (2012) sums up Said's thoughts on the endeavor of how it is to be an outsider cum public intellectual below:

Consequently, the intellectual needs to be in exile in order to develop his critical capacities for and free from the poisonous effects of dogmatic partisanship.... As Said affirms clearly in his book Representations of the Intellectual: "The pattern that sets the course for the intellectual as outsider is best exemplified by the condition of exile, the state of never being fully adjusted, always feeling outside the chatty, familiar world inhabited by natives.... Exile for the intellectual in this metaphysical sense is restlessness, movement, constantly being unsettled, and unsettling others. You cannot go back to some earlier and perhaps more stable condition of being at home; and alas you can never fully arrive, be at once in your new home or situation. (para. 4) 
Reynaldo Ileto (as cited by Sy-Hau, 2014 $)^{5}$ "[makes] a case for the 'power of the local intelligentsia' as a key medium between Philippine politics and scholarship" (p. 39). Instead of referring to the local intelligentsia as members of the middle class, Ileto calls them the "middle element. . . representing an indeterminate entity whose factions could put their talents to contradictory aims" (pp. 39-40). Sy-Hau shares Koki Seki's observation about members of the middle class who:

...[document] the boundary-making-and-breaching moves by which some members of the middle classes seek to differentiate themselves from the masses, on the one hand, and the upper classes, on the other hand, while others aspire for reforms and change through networking and alliances with the 'common people. (as cited by Sy-Hau, p. 42)

According to both Sy-Hau (2014) and Seki (2012), the Filipino academic cum public intellectual is, by default, part of this middle element or middle class that can engage with power due to its position in an elite state apparatus (the university) while displaying a degree of understanding of and co-mingling with the lower classes.

If one engages with powerful institutions as an outsider, then one need not be a learned scholar from the academe. Visual artists, musicians, playwrights, and novelists have been speaking truth to power for centuries. Their work has been memorialized in museums and reading lists; preserved as long playing albums (LP's) and compact discs (CD's); and re-experienced as stage performances.

In this paper, I remove the outsider from its spatial component and position it within notions of class. In the case of Gloc-9, for example, Katrina Santiago (2012) notes that Pollisco contextualizes his rapping without the need to "wear bling" or "fancy jackets" particular to the American context. Furthermore, all his songs are written in Filipino to address a specific audience, which contradicts the wave of scholarship produced by Filipino academics written mostly in English. ${ }^{6}$

\section{Gloc-9: The Artist and The Intellectual}

It is easy to fit Gloc-9, a self-confessed rapper and heir of the late Francis Magalona (Policarpio, 2013), into Said's conceptualization of the public intellectual and what that person does: challenge the social order; resist complacency; and to eschew the luxuries of a comfortable life. Gloc-9 challenges the elite establishment by rallying the marginalised, the oppressed, to recognize their position: othered, marginalised, peripheral. Accepting their marginalization supports hegemonic superstructures. Gloc 
9, like several musicians and artists before him, steps onto a dais of organic intellectualization to challenge language-art. Gloc-9 seeks to rouse the masses to recognize the corruption and ills of society. In February 2012, Gloc 9 admits that he feels compelled to write and sing about his encounters with abject poverty and helplessness. ${ }^{7}$ For him there is no other option (De Veyra \& Sabayton, 2012).

Gloc-9's discography reveals him as an artist who sets out to define who he is by stating in most emphatic terms what he is not. His first album, G9, establishes him as a rapper and hip-hop artist, not a rocker or an alternative artist. Taking his inspiration from Bone Thugs-N-Harmony, ${ }^{8}$ the commercially successful hip-hop group specializing in "interwoven, harmonious singing as well as rapping" (Birchmeier, n.d., para. 4), Gloc-9 produces verse following Bone Thugs's meter. Bone Thugs' popularity could best be attributed to what the Encyclopedia of Popular Music ("Bone Thugs 'n Harmony Biography," n.d.) has described:

[the] appealing blend of vocal harmonies and tough street raps, as featured on the hugely successful singles " 1 st $O f$ Tha Month" and "Tha Crossroads." Much of Stevie Wonders' smooth R\&B harmony style was brilliantly mixes with DJ U-Neek's hardcore beats, and even if their gangsta rapping became tiresome, the strength of tracks such as "Budsmokers Only" and "East 1999" managed to put it into the background. (para. 2)

In episode 10 of Wasak, a late-night television talk show ${ }^{6}$ hosted by Lourd de Veyra and Jun Sabayton (2012), Gloc-9 explains how he practices saying simple phrases faster and faster, always following the natural cadence of speech. Never counter temporal, he employs a straightforward 4/4 meter; he displays the basic rudiments of a learned percussion player with impeccable timing. He is easily able to insert offbeat syllables without losing tempo. He shares how his music flows naturally and is not a learned skill (De Veyra \& Sabayton, 2012).

Gloc-9's charm and power as rapper and performer lies in his candid admission of ignorance when it comes to music and its technicalities. However, it is also quite evident in the Wasak interview that Gloc 9 is not ignorant of music conventions and styles (De Veyra \& Sabayton, 2012). He is able to locate his music within the rubric of genres and to demonstrate varying meters and tempos in explaining how he creates his songs. His disarming explanation of how he crafts his messages through his music shows that one need not be an ideologue or intellectual in order to engage 
with both institutions of power and the marginalized with whom he steadfastly identifies.

On his official website, Gloc 9 is described thus by Santiago (2011):

Moving from love and dance rap to socially relevant music, Gloc-9's songwriting is one that's unique in these shores premised as it is on his own personal history of struggle, yet refusing as it does narcissism or selfaggrandizement. Here are songs that insist on looking at nation, with compassion on the one hand and fearlessness on the other, where the demand for fundamental change is cloaked in words familiar and painful... [emphasis added]

In the past three years Gloc-9 has risen to become the one Filipino musician to bravely engage with the travails of nation. That he has been embraced by mainstream television and radio while he has remained unflinching in his critical stance about current society, therein lies his music's power. Pinoy rap lives. And his name is Gloc-9.

Si Gloc-9 ay umusbong hindi bilang rapper kung di bilang tao mula sa Binangonan Rizal, tagahanga ni Francis $M$, naging empleyado $n g$ fastfood chain at $n g$ malaking media company bilang music researcher, bago na-diskubre bilang rapper. Gumawa ng love at dance rap, ngunit paglao'y makikilala sa paggawa ng mga kantang patungkol sa personal na pakikipamuhay sa araw-araw ng kahirapan, sa harap ng krisis ng tunggalian sa Pinas na kinalakhan.

Walang patumangga ang pakikilahok ni Gloc-9 sa mga usaping bayan. At sa panahong yinakap na siya ng telebisyon at radyo, nagiging mas malinaw pa ang halaga ng pakikilahok na ito. Ito ang hinihingi ng kasaysayan sa bawat manggagawa sa sining, at ito ang hindi ipinagkakait $n g$ kanyang panulat. Iisa ang pangalang katumbas ng Pinoy rap sa panahong ito. Ang pangalang ito ay Gloc-9.

[Gloc 9 gained fame not as a rapper but as a simple man from Binangonan, Rizal, an avid admirer of Francis $M$, a fastfood chain employee and music researcher of an established media company, before he was discovered as a rapper. He composed love and dance rap, and when his star has dimmed he will be known for writing songs about the 
personal travails of daily living, through crisis and conflicts in his troubled homeland, the Philippines.

Gloc-9 takes a no-nonsense approach in tackling national issues. At a time when he is a mainstay on TV and radio, the significance of his engagement cannot be ignored. It is what the times demand of every artist and he does not disappoint. When one thinks of Pinoy rap there is only one name that comes to mind and this name is Gloc-9.] (para. 1-4)

To address issues of social importance, a public intellectual engages in public discourse, challenges the status quo, and questions the hegemonic discourse that surrounds cultural rites and traditions embedded in social structures and institutions. Said declares that pubic intellectuals need to advance freedom and knowledge. Whether or not he or she is prompted, the intellectual is obligated to speak the truth, not merely react. This is what it means to engage relevant issues instead of waiting for events to transpire. According to Jahanbegloo (2012):

Edward Said elaborated on the social, political, and moral responsibility of the intellectual, and on his concept of the intellectual as an oppositional figure. He offered this challenge to the intellectual: "No one can speak up all the time on all the issues. But, I believe, there is a special duty to address the constituted and authorized powers of one's own society, which are accountable to its citizenry, particularly when those powers are exercised in a manifestly disproportionate and immoral war, or in a deliberate program of discrimination, repression, and collective cruelty." (para. 12)

Gloc-9's body of work includes songs that speak against discrimination of the weak and oppressed: homosexuals ostracized in "Sirena" [Mermaid] ; prostitutes exploited in "Magda"; and children being bullied in "Antinganting" [Magic Charm]. Some of his songs are outright indictments against the excesses of the rich and powerful: "Upuan" [Seat] and "Kunwari" [Pretense]. His song, "Walang Natira" [Nothing Left], empathizes with Overseas Filipino Workers (OFWs) whose families were separated in the struggle to find meaningful occupation.

The nature of gangsta rap from which Gloc-9 derives much of the ethos of his work falls within what Charis E. Kubrin (2005) describes as a street code characterized by the valorization of sex, misogyny, violence, and 
substance abuse. This code was produced by the economic degradation of disadvantaged communities in the inner cities, which Tricia Rose (1994) describes as having "limited avenues for adolescents to obtain the types of social status and social roles available to youth in other environments" ( $\mathrm{p}$. 362). She expands this discussion with Lawrence D. Wieder's (as cited in Kubrin, 2005) assertion:

[T] he code represents more than a normative structure available to members of a setting as well as to the researcher of their behavior: it is a set of interpretive guidelines that was variably conjured up by the residents themselves who used it to account for matters that required explanation. In other words, "the code was a living embodiment of social control, serving as a shared accountability structure for residents' actions. (p. 366).

Levinson's (2001) discussion of the language-arts of discourse on Gramsci's subaltern can be mapped out within the type of discourse or street code that Gloc-9, as an organic intellectual, employs in order to describe what he himself has witnessed and experienced. Gloc-9's economically disadvantaged background enables him to speak about others in similarly disadvantaged situations enshrined within the conventions of gangsta rap's street code, which stands as a marker of his social identity.

During the Wasak (De Veyra \& Sabayton, 2012) interview, Pollisco narrates that as a nursing intern in the emergency and delivery rooms of government hospitals, he described the conditions of birthing mothers as akin to being in a pigpen. He watched row upon row of women in labor giving birth in the most harrowing conditions, declaring that even the toughest Tondo bigwig would buckle from the slightest amount of pain that a birthing mother experiences. Pollisco watched poor women die from childbirth which drove him to songwriting and left him shaken and disturbed. In the face of so much suffering and injustice, he could not remain silent. He revealed that he struggled to complete his nursing degree at STI (Systems Technology Institute) to teach his children the virtue of striving to accomplish what needs to be done in spite of the hardships and struggles.

In a succeeding section of this paper I will discuss the cool and dapper image that Gloc-9 developed for his television persona, yet another component of the street code that "highlights the appreciation for material wealth as another way to establish self-image and gain respect" (Kubrin, 2005, p. 364). Acquiring indicators of success and overcoming economic impediments place Gloc-9 in a revered position. Made respectable by 
material gain, he can represent and engage with those in the same situation while speaking of the hardships he experienced. His songs address members of the elite who disdain people like them, and economically oppressed people who may not understand the conditions that consign them to a humiliating and degrading existence.

\section{Gloc-9 and the Jologs Nation}

What does it mean to be "jologs"? When Gloc-9 speaks of "we" as being jologs in his anthemic song of the same title, he appropriates a pejorative term used to refer to anyone whose tastes in cultural matter (i.e. music, movies, reading material, to name a few) would be considered baduy or kitsch. ${ }^{9}$ The term rose to prominence in the aftermath of the 2001 uprising called EDSA 3 , which was composed mainly of Metro Manila's urban poor who rallied to reinstate former President Joseph Estrada after he was impeached in the wake of street demonstrations spearheaded by the middle class elites. Marco Garrido (2008) and Rolando Tolentino (2005) question how EDSA 3 was criminalized and dismissed as unruly crowds who desecrated the EDSA shrine.

Garrido (2008) explores the binary of $m a s a^{10}$ vis-à-vis "di-masa" and describes the masses as a "primary connotation of vulgarity closely associated with poverty, a lack of refinement, and ignorance. It came to mean something like 'the great unwashed', indicating ironically the excesses of democracy" (p. 451). He proceeded to describe the masa "as a noun, it is usually a way of characterizing the poor as politically, morally, and aesthetically backward" (p. 451). He records how middle-class women describe class distinctions. His respondents describe the masa as those who read tabloids, watch Eat Bulaga (a long-time running daily noontime variety show littered with getrich-quick games and bawdy, slapstick humour), talk loudly inside "jeepneys" (mass transport conveyances exposing riders to pollution in deplorable standstill traffic) with their mouths open, and are prone to garish excesses in their choice of clothes or manner of throwing gaudy parties.

Tolentino (2005) critiques Garrido's characterization of "the poor as politically, morally, and aesthetically backward" (p. 451) in ten vignettes or dagli that present micro sections culled from popular fashion trends and economic treatises to explain the rampant political, economic, and cultural debasement. One vignette was subtitled "Jologs," to refer specifically to the dissident urban poor who mounted street demonstrations after President Joseph Estrada was impeached by similar demonstrations led by the middleclass and the clergy. The protests gained traction after the capitulation of the military led by former President Estrada's Defense Secretary Orly Mercado (p. 342). In this $6^{\text {th }}$ dagli, Tolentino describes the jologs as people whose 
outcry of rage and resentment against the establishment was belittled because they are dirty, crass, and simply too pedestrian to be taken seriously. Tolentino ends this section ironically: depicting disinterested bourgeoisie in their comfortable homes watching news of the jologs being dispersed after desecrating the shrine with human waste and trash.

Although Brett Levinson (2001) locates the term "queer" within issues of violence, injustice, and instability, a similar argument might be made for the jologs and jejemon in Philippine society. Levinson explains that the pejorative uses of such terms "[exposes] the subaltern, permitting him to feel his alienation and exploitation" and that the constant use of such terms "raises and marks the subaltern's sense of being misrepresented or wronged" (p. 66).

On the other hand, Gramsci (as cited in Levinson, 2001) described subalterns as "underclass, agrarian Southerners and Sardinians. . . alienated not because they are too estranged [but because they are] not estranged enough" (p. 66). He argues that negative attitudes towards the subaltern-the jologs or jejemon-become naturalized and enter the hegemonic discourse. The jeje accepts the subaltern position, and this paradoxical embracing of one's otherness is naturalized with the use of their particular language or dialect, or language-art. Levinson argues:

As dialect, then, the Gramscian language-art serves as a tool within civil society or the public sphere. . it awakens a certain self-consciousness, [p] otentially bringing together peoples who, through collective activity, grow aware of themselves or create themselves as a community with a shared history, idiom, and territory[;] the dialect turns into a mechanism by means of which peripheral worlds initiate actual rallies. Public practices, new institutions, popular art forms, and regionalisms all can materialize through the new articulations. (p. 69)

Gloc-9 uses his sense of exile to access a metaphorical level of the language of the masses, Filipino-in his case, Tagalog, which accounts for 90\% of Filipino vocabulary-and not English-to advance freedom and knowledge.

Lynda Dee Dixon Bowling and Patricia A. Washington (1999) examine the voices in rap music videos of urban African-American males, contending that "rappers' perspectives reveal dilemmatic issues that constitute the belief systems of 'organic intellectuals' and gangsta figures in rap" (para. 10). The nature of rap and gangsta, Bowling and Washington assert, rest in the fact that rap is a genre of the "dispossessed... voices of outlaws and outsiders... 
rap... praise[s] the hero outsmarting the oppressive establishment... and frequently catalogue internal as well as the external sources of social problems plaguing their communities of residence" (para. 17). While this study addresses the subaltern voices of African-American rappers, the point that can be drawn from this is the "re-construction of their reality through the discourse of rap" (para. 13). Both researchers cite Dyson (1991) in the claim that such voices "...project a style of self onto the world that disciplines ultimate social despair into forms of cultural resistance, and transforms the ugly terrain of ghetto existence into a searing portrait of life as it is lived by millions of voiceless people" (Dyson, 1991, page 24). The ghettos of America's inner cities can be transposed into the swelling slums of Metro Manila where the urban poor live in cramped, filthy quarters.

Although Gloc-9 seeks to identify with the oppressed, as he does in the song "Jologs," he remains part of mainstream music as evidenced by his music videos, the world of music awards and glamour of show business, and close association with hip-hop celebrities such as FrancisM (Francis Magalona) and Chito Miranda who are both Gloc-9's close friends. Gloc-9 reveals that Francis Magalona stood as godfather to his twin children (De Veyra \& Sabayton, 2012).

Appropriating the language and conventions of gangsta rap, Gloc-9's success gives him the authority to turn to the didacticism prevalent in his music videos. Despite his authority and inclusion in high society, Gloc-9 employs the guttural speech of the masses in rapid, spitfire hip-hop.

Gloc-9 steps into the role of the non-academic intellectual or authority figure speaking from outside institutional hegemonic production. While purportedly non-elitist, Gloc-9 speaks for the people with whom he relates and for whom he offers his music. On their behalf, he speaks of the truth about power to emancipate listeners from an oppressive mindset, patronage politics, and coddling the nation's greediest businessmen and politicians.

Gloc-9 came under heavy criticism in early 2016 when he performed at campaign rallies for former Vice President Jejomar Binay and his daughter Abigail Binay, a presidential candidate and mayoral candidate respectively ("What Gloc-9 Says," 2016). He was branded a hypocrite for writing relentlessly against political greed in "Upuan" [Seat] and "Dapat Tama" [Do What Is Right] and then endorsing a candidate accused of graft and corruption (Sabillo, 2016). Gloc-9 released statements on Twitter and Facebook ("Gloc-9 Breaks His Silence," 2016) to explain that he was only a performer-for-hire and that any apology he owed, he owed only to his children ("What Gloc-9 Says," 2016). The furor over his appearances at such rallies was testament to his huge emotional appeal and the level of his influence. His fans take his songs to heart, especially politically-charged 
songs such as "Upuan." One such fan, Marvin Reyes, posted this status to his FB wall on March 29, 2016, two days after Gloc-9's performance at Binay's rally: "Gloc 9 supporting Binay. His songs are now meaningless. Deletes 'Upuan"' (Reyes, 2016).

In his analysis of thirteen Gloc 9 songs, Feorillo Demeterio III (2013) argues that the rapper focuses on specific experience suffered by the urban poor:

[This] study demonstrates that some of the images that Pollisco has used in his own social and political criticism nestle some contradictions brought about by lack of preparedness for ideological criticism. The images culled from the thirteen songs are grouped under five themes: corruption and politics, nationalism/patriotism, poverty and the life of workers, crime and disorder, and homophobia. (p. 17)

Gloc addresses Jologs Nation in a song of the same title. It reveals the duality of his organic, public intellectual persona: both hip-hop rap artist in live performances and a smooth talking, suited, dapper intellectual.

In "Jologs" from the album G9 (2003) , Gloc 9's reveals the shades and contours of his nation. It is a nation of baduy, cheap, jeje people in the periphery who are constantly othered and perpetually marginalized. The song alludes to those who occupy the lower rungs of the social order.

Chorus:

Jologs kami na kung tawagin ay mga

Jologs taong hindi katulad ng iba

Jologs sila na kung tawagin ay mga

Jologs kaya mo bang maging tulad nila

Jologs kami na kung tawagin ay mga

Jologs taong hindi katulad ng iba

Jologs sila na kung tawagin ay mga

Jologs sana'y wag mong husgahan sa mata

Uologs - is how we are thus called

Jologs - are people unlike others

Jologs - fine, so we are labelled as thus

Jologs - can you be called thus and be like us?

Jologs - is how we are thus called

Jologs - are people unlike others

Jologs - are people unlike others

Jologs - fine, so we are labelled as thus

Jologs - may you not judge what you see] 
Gloc-9 assumes a persona akin to a chimera: moving in and out of "we" and "they"; simultaneously inclusive and didactic, speaking as one of jologs and then shifting to speaking about jologs. Gloc 9 embodies one who navigates discourse. Although he belongs to the periphery, he must command respect as a public figure to communicate his message. He is both jologs and didactic authority figure: crass yet educated, vulgar yet circumspect, irreverent yet respectable.

In his live performances, Gloc-9 is the simple, down-to-earth, fasttalking rapper who closes his eyes, sways from side to side, and gesticulates with his hands towards his audience. He keeps his messages simple and to the point. In a 2013 interview with Allan Policarpio (2013), he reveals that his ability to empathise with fans as a music fan himself inspires to write from the heart.

Rap originated from the Bronx, New York, as a form of resistance and self-expression. In an ethnographic study of rap in African-American cultures, Cheryl Keyes (1996) wrote that research on rap and other youth culture music

...revealed that rap music expresses the everyday harsh realities of ghetto life and socio-political sentiments ranging from poverty, police brutality, and racial genocide to class and gender relations by an urban black youth constituency. Although these studies were primarily drawn from lyrical analyses rather than ethnographic inquiry, they nevertheless remain important in comprehending rap as a form of resistance and contestation. (p. 224)

In his music videos, Gloc-9 is more polished and circumspect. Although the message remains the same, Gloc- 9 as the suited rapper is a sharp turnaround from the head-banging Gloc-9 that live audiences love and adore. In the music video "Sirena," (Pacena, 2013b) when he says, "Di sinusukat ang tapang at ang bigote sa mukha/Dahil kung minsan mas lalake pa sa lalake ang bakla" ["One does not measure courage by one's mustache/ It is oft the case that a queer is more male than a straight male"], he looks directly into the camera and delivers the lines clearly for effect. In "Magda," (Pacena, 2013a) a song about a provincial girl who resorts to prostitution, there is a reversal of roles between Gloc-9 and his co-collaborator, Rico Blanco, former vocalist and lyricist of the popular rock band Rivermaya. Gloc-9, in a dark blazer, has done away with the tie but retains a veneer of dignity as he embodies Magda's provincial paramour. Stumbling into a nightclub, he discovers her stripping onstage. Blanco emerges from the dark confines and sings the chorus in a somber tone. In this song, Blanco is 
narrator while Gloc- 9 becomes the voice of the male protagonist.

The above songs are just two examples of successful collaborations that have won Gloc-9 multiple awards from Myx, Awit, and PMPC Star (“Tungkol kay Gloc-9," 2012). Described by FrancisM as a "blacksmith of words and letters, and a true Filipino poet" ("Blacksmith of Words, Disciple of Rap," 2012, para. 21), both songs display Gloc-9's penchant for a straightforward premise. He defends the rights of those who are oppressed and discriminated against in society: women and members of the LGBT. Commercially successful songs help propel issues of gender and sexual inequality into the public consciousness. Gloc-9 is the only Filipino rapper lauded as the people's favorite in Myx and Awit awards for every album he has produced.

\section{In Live Performances: Gloc-9 the Hiphop Artist}

Gloc-9's public space juxtaposes the physical spaces he inhabited as a young man, and digital space. In his live gigs and performances, Gloc 9 wears a $\mathrm{t}$-shirt, loose jeans, and sneakers.

In his Wasak interview, he explains that he does not want to be "too maporma" ["too dressy"] for fear of being accused of being arrogant by his fanbase (De Veyra \& Sabayton, 2012). He is accessible to his supporters because he dresses like them and sounds like them. His fans can relate to him.

In addressing jologs nation, Gloc-9 fuses decidedly Western hip-hop conventions with Filipino style: [in Filipino; writer's paraphrase follows], 'If you want to serve them shrimp, as I try to do, and yet they're accustomed to siopao, then I need to find a way to serve them shrimp siopao in order to be accepted" (De Veyra \& Sabayton, 2012).

\section{In Music Videos: Gloc-9 as Intellectual}

I am jologs [kami na kung tawagin]. I speak of them [sila na kung tawagin] and I am like them. We are different from you [taong hindi katulad ng iba] and you, unnamed non-jologs listener. Do not judge us for not being burgis [wag mong husgahan sa mata].

The song "Jologs" reveals Gloc-9's shifting persona. He rails against materialism while explaining why we jologs wear what we wear: clothes are expensive and we really don't care what we wear. Hell, we don't mind when we smell because that's just how we are because that's just how it is.

Garbed in an expensive, tailored suit, Gloc-9 commands respect by embodying success and authority. This aura of respectability cloaks the rough, guttural language-art of hip-hop associated with an emasculated group. This tension enables Gloc-9 and his listeners to resist hegemonic 
discourse, to rail against injustices, to expose condescending treatment against them, and to fight back.

"Upuan" [Seat] was a collaboration with Jaezell Grutas, from the female rock group Zelle, allowed Gloc-9 to seduce the listener with his message, a scathing condemnation of the excesses of those in power. Demetrio (2013) states that the specific target of the song is the President of the Philippines himself. The song alludes to Malacañang Palace by describing a mansion situated amidst much squalor. The juxtaposition reveals the insensitivity of the inhabitant to the suffering that the poor endure just outside his doorstep:

Chorus (Jeazell Grutas of Zelle):

Kayo po na naka upo,

Subukan nyo namang tumayo

At baka matanaw, at baka matanaw na nyo

Ang tunay na kalagayan ko

[You who sit in power

Why don't you try and stand up

That you might see

My true circumstances]

Verse 1 (Gloc-9):

Ganito kasi yan eh...

Tao po, nandyan po ba kayo sa loob ng

Malaking bahay at malawak na bakuran

Mataas na pader pinapaligiran

At naka pilang mga mamahaling sasakyan

Mga bantay na laging bulong ng bulong

Wala namang kasal pero marami ang naka barong

Lumakas man ang ulan ay walang butas ang bubong

Mga plato't kutsara na hindi kilala ang tutong

At ang kanin ay simputi ng gatas na nasa kahon

At kahit na hindi pasko sa lamesa ay may hamon

Ang sarap sigurong manirahan sa bahay na ganyan.

[Let me explain this to you...

Pardon me, you who live in

Huge mansions with wide lawns

Surrounded by high walls

With rows of expensive cars

Under the watchful eye of security who speak in whispers 
There is no wedding yet why are there so many wearing formal clothes

If storms come your roofs are impervious to leaks

Your plates and utensils will never know what burned rice feels like

Your rice is as white as milk that comes in cartons

Even if it is not yet Christmas your tables overflow with ham

How nice it must be to live inside such a house]. (Pollisco, 2009)

Demeterio (2013) points out that Gloc-9's critique of political excesses bespeaks a lack of vision or direction: while Gloc-9 is quick to criticize the heartlessness of those in power, he fails to point out that a collective engagement and questioning of social injustice by the poor can put an end to the foolery that politicians are only too casual to dispense. While such an observation has its merits, it smacks of a certain academic smugness. It is as if Demeterio is forcing Gloc-9 to become an engaged public intellectual via his songs.

Gloc-9's songs critical of politicians cannot be forced to yield the type of critical discourse that is par for the course among academics. Gloc-9's situation and context calls for a different response and agency.

In "Kunwari" (Pollisco, 2014), a song produced in collaboration with Kamikazee, Gloc- 9 comments on the excesses of the rich and powerful by explicitly castigating the campaign maneuverings of politicians. What is notable in the music video is the frenzy and abandon that both Gloc-9 and Jay Contreras, Kamikazee's lead vocalist, indulge in by way of ferociously delivered lines and head-banging.

Gloc-9 collaborated with Ebe Dancel on the hit song "Sirena" (Pollisco, 2014) to represent the voice of the young male queer, also known as sirena. He also consulted with the community of gay writers and celebrities including: Danton Remoto, spokesperson for Ladlad, a political party representing LGBT rights; Carlos Vergara, creator of the cult graphic novel Zsazsa Zaturnnah; Tuxs Rutaquio, director and stage actor; and Boy Abunda, the famous TV personality and host.

"Sirena" became one of the biggest commercial musical hits of 2012. Gloc-9 admitted that the reception and popularity of the single took him by surprise (De Veyra \& Sabayton, 2012). Exceeding ten million YouTube downloads in 2013, this is arguably one of Gloc 9's most popular songs as it addresses the pervasive issue of homophobia entrenched in a patriarchal society (Demeterio, 2013). The song tackles homophobia as it is normalized or mythicized in its repeated use of the term sirena (or mermaid) to describe 
the queer, pubescent male as half beast and half human. Demeterio is clearly unhappy with how Gloc-9 uses the demeaning image of half-male, halffemale to refer to gay men. The song establishes that the redeeming quality of the young boy is achieved by his filial piety to the ageing father, a revered virtue in Philippine society. However, Demeterio points out that the father signifies a metaphorical patriarchal figure that continues to determine the destiny of his queer son.

For the respective music videos for "Sirena," "Magda," and "Upuan" Gloc-9 is attired in a coat and tie. Jaezell Grutas and Sheng Belmonte, his female collaborators, are seductive and sinuous, while Ebe Dancel and Rico Blanco are stoic and similarly dressed as Gloc-9. Dancel and Blanco represent the weaker feminine personas of the sirena and the biblical Magdalena. The sexualization of the female collaborators raises the ever-present specter of gender discrimination. When Gloc-9's male collaborators voice the troubled queer boy or narrate the sad tale of the provincial lass fallen prey to the sexual appetites of an uncaring metropolis, the videos reinforce the need to fight certain stereotypes.

Gloc-9 would have other collaborations with other stars on similar projects containing socially relevant themes: an anti-bullying campaign with Spongecola and the problematic plight of public teachers turned OFWs with Sheng Belmonte.

\section{In person and On screen: Gloc-9 as Chimera}

Chomsky (as cited in Tresilian, 2010) derided the notion of speaking truth to power, calling it a presumptuous exercise. According to Chomsky, people who consider themselves co-equals would not be pedantic with each other. More importantly, for Chomsky, the concern is not so much with the powerful as it is with those who are victims of power and its trappings:

First of all, you don't have to speak truth to power, because they know it already. And secondly, you don't speak truth to anybody, that's too arrogant. What you do is join with people and try to find the truth, so you listen to them and tell them what you think and so on, and you try to encourage people to think for themselves. The ones you are concerned with are the victims, not the powerful, so the slogan ought to be to engage with the powerless and help them and help yourself to find the truth. It's not an easy slogan to formulate in five words, but I think it's the right one. (para 41)

Christopher Hitchens (2008) drolly sums up the plight of the public intellectual thus: 
Indeed, one might do worse than to say that an intellectual is someone who does not, or at least does not knowingly and obviously, attempt to soar on the thermals of public opinion. There ought to be a word for those men and women who do their own thinking; who are willing to stand the accusation of "elitism" (or at least to prefer it to the idea of populism); who care for language above all and guess its subtle relationship to truth; and who will be willing and able to nail a lie. If such a person should also have a sense of irony and a feeling for history, then, as the French say, "tant mieux." An intellectual need not be one who, in a well-known but essentially meaningless phrase, "speaks truth to power." (Chomsky has dryly reminded us that power often knows the truth well enough.) However, the attitude toward authority should probably be skeptical, as should the attitude toward utopia, let alone to heaven or hell. (Hitchens, 2008, p. 64)

Gloc-9 does precisely this when he raps to speak of the truth with his fellow jologs in "Jologs Nation." His didactic tone and suit aside, Gloc-9 speaks for the masses when he lambastes the rich and powerful for their greed and excesses. The hope is that the urban poor for whom he speaks can receive snippets and glimpses of truth, and begin to weave a destiny for themselves that breaks free from oppression and patronage politics.

\section{Conclusion: An Alternative Image, Alternatively Intellectual}

In the video, "Kunwari" [Pretense], Gloc-9 collaborates with Kamikazee lead vocalist Jay Contreras. "Kunwari" (Pollisco, 2014) is a fast-paced number that breathlessly lambastes politicos during campaign season for their empty promises and greedy ways. Gloc-9 button up his polo shirt up to the neck to differentiate himself from Jay Contreras. Gloc-9 and Contreras stand on the pulpit and parody the greedy politicians they lambast with unrelenting energy the excesses of the country's politicians. It is vintage Gloc-9, the fastest rapper in the country, speaking out against those in power. In this particular music video, Gloc-9's effect and impact as one who speaks truth to the powers that be, and as an organic intellectual from the peripheries, is most raw, potent, and powerful. In embracing the pathos of the marginalized, Gloc- 9 can effect more meaningful social change when he remains true to himself and his roots. The message is not lost without the dapper suits. In dispensing with the didactic image of the intellectual in formal attire, Gloc-9 and Contreras become one with the masses that they seek to embody and the frothing, seething message of resentment boils over 
in reckless abandon. It is the ultimate celebration of the carnivalesque: if only for a few moments, lost within the wild rush of the screaming lyrics, both artists upend the class status quo. Fans of both singers can rush into the space created by their performance and celebrate the triumph of the lowly against the entrenched powerful.

With manic intensity and drive, Gloc-9 is feral and visceral in his ceaseless percussive rap harangue. By foregoing the image of the formally dressed and successful rapper who escaped the ghetto into the realm of intellectual discourse, the language-art of his songs maintain their heft and clarity. While Gloc-9 bears the burden of speaking truth to the powers that be, it is a task that he assumes with much trepidation. 


\section{References}

Australian National University. (2016, November 30). Dr Reynaldo Ileto. (R. S. Division, Producer) Retrieved from Australian National University:https://researchers.anu.edu.au/researchers/ileto-rc/.

Bakhtin, M. M. (1994). From Rabelais and his world (1965). In P. Morris (Ed.), The Bakhtin reader: Selected writings of Bakhtin, Medvedev and Voloshinov. London, United Kingdom: Edward Arnold.

Birchmeier, J. (n.d.). Bone Thugs-N-Harmony. All music. Retrieved from http://www.allmusic.com/artist/ bone-thugs-n-harmony-mn0000081316/biography.

Blacksmith of words, disciple of rap. (2012, June 12). Manila Bulletin Lifestyle. Retrieved from https://www. highbeam.com/doc/1G1-292825319.html.

Bone Thugs 'n Harmony Biography. (N.d.). Retrieved from https://www.oldies.com/artist-biography/ Bone-Thugs-N-Harmony.html.

Bowling, L. D. D. \& Washington, P. A. (1999). Rap music videos: The voices of organic intellectuals.

Retrieved from http://www.sibetrans.com/trans/articulo/255/rap-music-videos-the-voices-oforganic-intellectuals.

Lenin, V. (1966). What is to be done. In H. Christman (Ed.), The essential works of Lenin (pp. 53-176).-New York: Bantam Books.

Demeterio III, F.P. (2013). Isang semyolohial na pagsusuri sa mga kontradiksyong nakapaloob sa panlipunang kritisismo ni Gloc-9. Malay, 26(1), 17-35.

De Veyra, L., \& Sabayton, J. (Interviewers). (3 February 2012). Wasak Episode 10, Season 1 (Interaksyon). Quezon City: Metro Manila.TV5

Dyson, M. E. (1991). Performance, protest, and prophesy in the culture of hiphop. Black Sacred Music: A Journal of Theomusicology, (5), 2-24.

Garrido, M. (2008). Civil and uncivil society symbolic boundaries and civic exclusion in Metro Manila. Philippine Studies: Vanua in Batanes, 56(4), 443-465.

Francis Magalona Biography. (n.d.). IMDb. Retrieved from http://www.imdb.com/name/nm1052850/bio.

Hall, S. (1986). Gramsci's relevance for the study of race and ethnicity. In D. M.-H. Chen (Ed.), Stuart Hall: Critical dialogues in cultural studies (pp. 411-440). New York: Routledge.

Heflin, K. (2008, January). Building resistance from within: Resistance, contradiction and the emancipatory potential of organic ideology. Paper presented at the annual meeting of the National Communication Association. San Diego: National Communication Association

Hitchens, C. (2008). The plight of the public intellectual. Foreign Policy, 166, 62-64.

Jahanbegloo, R. (2012, October 15). Edward Said's conception of the public intellectual as an "outsider." Retrieved from http://jahanbegloo.com/content/edward-saids-conception-public-intellectualoutsider.

Keyes, C. L. (1996). At the crossroads: Rap music and its African nexus. Ethnomusicology, 40, 223-248. Chicago: University of Illinois Press.

Kubrin, C. E. (2005). Gangstas, thugs, and hustlas: Identity and the code of the street in rap music. Social Problems, 52(3), 360-378.

Levinson, B. (2001). Feeling, the subaltern, and the organic intellectual. Angelaki: Journal of the Theoretical Humanities, 6(1), 65-74.

Newfitness.co. (2016, March 30) Gloc-9 Breaks His Silence on Performing at Binay's Campaign Rally! 
Newfitness.co. Retrieved October 31, 2017 from http://newfitness.co/2016/03/30/gloc-9-breakshis-silence-on-performing-at-binays-campaign-rally/.

Olsaretti, A. (2014). Croce, philosophy and intellectuals: Three aspects of Gramsci's theory of hegemony. Critical Sociology, 42(3), 337-355.

Pacena, J. (2013a). Magda [Music video]. Manila: Universal Records

Pacena, J. (2013b). Sirena [Music video]. Manila: Universal Records

Policarpio, A. (2013,December). He raps, writes from the heart. Inquirer.net. Retrieved from http:// entertainment.inquirer.net/124673/he-raps-writes-from-the-heart.

Pollisco, A. (2009) Upuan. On Matrikula [CD]. Manila: Universal Records.

Pollisco, A. (2014) Sirena. On Liham at Lihim [CD]. Manila:Universal Records.

Pollisco, A. (2014) Magda. On Liham at Lihim [CD]. Manila: Universal Records.

Pollisco, A. (2014) Kunwari. On Liham at Lihim [CD ]. Manila: Universal Records.

Rappler (2016, March 30). Gloc-9 speaks up about performing at Abby Binay rally. Rappler. Retrieved October31,2017 from http://www.rappler.com/entertainment/news/127551-gloc-9-managementclarifies-performance-abigail-binay-makati-sortie.

Reyes, M. (2016, May 2016). Gloc 9 supporting Binay. His songs are now meaningless. Deletes "Upuan".In Facebook [Status post]. Retrieved from https://tinyurl.com/y7hpfx69.

Said, E.W. (1978). Orientalism. New York:Vintage Books.

Sabillo, K. A. (2016)."Gloc-9 defends self after performing at a Binay rally". Retrieved from http:// entertainment.inquirer.net/192947/gloc-9-defends-self-from-bashers-after-performing-at-binayrally.

Seki, K. (2012). Difference and alliance in transnational social fields: The pendular identity of the Filipino middle class. Philippine Studies: Historical and Ethnographic Viewpoints, 60(2), 187-222.

Santiago, K. S. (2011, April 5). Gloc-9: A Pinoy rapper and his painful truths. GMA ews Online. Retrieved from http://www.gmanetwork.com/news/story/216918/lifestyle/gloc-9-a-pinoy-rapper-and-hispainful-truths.

Santiago, K. S. (2012, February).Tungkol kay Gloc-9. Retrieved from Gloc 9: http://glocdash9.com/about/. Sy-Hau, C. (2014). Privileging roots and routes: Filipino intellectuals and the contest over epistemic power and authority. Philippine Studies: Historical and Ethnographic Viewpoints, 62(1). Quezon City, Philippines: Ateneo de Manila University.

Tolentino, R. (2005). Sampung dagli. Philippine Studies: Mga Bagong Akda (New Writing), 53(2/3), 336-347. Tungkol kay Gloc-9. (2012). Retrieved from http://glocdash9.com/about/\#awards.

Tresilian, D. (2010, June). Noam Chomsky: speaking of truth and power. Al-Ahram Weekly Online. Retrieved from: http://weekly.ahram.org.eg/Archive/2010/1001/intrvw.htm.

What Gloc-9 says on performing for Binays. (2016, March 30). ABS-CBN News. Retrieved from http://news. abs-cbn.com/entertainment/03/30/16/what-gloc-9-says-on-performing-for-binays. 


\section{Endnotes}

${ }^{1}$ See Said's (1978) Ch. 1,"Knowing the Oriental", for the development of his argument as he presented it before the Parliament, arguing for the continued domination of the Orientals in light of their relative ignorance or lack of awareness in self-governance.

${ }^{2}$ Caroline Hau (2014) points out that Said, in his seminal postcolonial work, Orientalism (2000), "writes of the need to distinguish among exiles, refugees, expatriates, and emigres, but chooses to stress the commonalities - rooted in solitude and estrangement - rather than differences among them" (p. 57).

${ }^{3}$ For Lenin (1966), "Class political consciousness can be brought to the workers only from without, that is, only outside of the economic struggle, outside the sphere of relations between workers and employers. The sphere from which alone it is possible to obtain this knowledge is the sphere of relationships between all the various classes and strata and the state and the government-the sphere of the interrelations between all the various classes" (p. 112).

${ }^{4}$ To quote from Heflin (2008):"Vanguardism is based on the notion that for a successful revolution to occur, it must have leaders from outside the working class who bring a 'class political consciousness' to the working class" (p. 19).

${ }^{5}$ Biographical notes on Reynaldo lleto's works are listed here: https://researchers.anu.edu.au/ researchers/ileto-rc. He is described in Wikipilipinas Hip and Free Encycolopedia ("Reynaldo lleto," n.d.) "the father of the movement of writing 'history from below.' Unorthodox historiography uses folk oral literature and traditions such as the pasyon and even travel photographies to retell standard history, which is normally studied using official sources" (para. 1).

${ }^{6}$ Sy-Hau (2014) writes "Scholarship in English and produced in metropolitan centers tends to be read and cited more often than scholarship in Filipino and other languages" (p. 54).

${ }^{7}$ In particular, I'm referring to his tale recounting the times he served as a nursing intern at a government hospital and saw how patients in dire condition would not be treated unless they presented proof of payment. Such moments would rend him apart and he would vow to himself to write and sing about such instances.

${ }^{8}$ As described thus by Birchmeier (n.d.), the Bone Thugs are"... [g]raced with a quick and sometimes sung delivery, along with a unique sense of melody, Bone Thugs-N-Harmony burst out of Cleveland, Ohio in the mid-'90s with a pair of massive hits ("Thuggish Ruggish Bone" and "Tha Crossroads") along with a great first album, as well as a successful follow-up, and then quickly unraveled. Mainstream interest dropped off toward the tail end of the ' $90 \mathrm{~s}$, but the group, which underwent a series of lineup changes, continued to release new material via mixtapes and albums throughout the 2000s" (para. 1).

${ }^{9}$ Other terms associated with kitsch are baduy, wa class (from walang class, literally without class or breeding), bakya (literally wooden shoes worn in the rural areas by baseborn people or those lacking the sophistication to wear shoes as the city folk do), promdi (an abbreviation of 'from the' province, pejoratively used). Garrido (2008) further explains that such terms "evoke the image of unsophisticated provincial migrants to the city" (p.450). 
${ }^{10}$ Garrido (2008) traces the changing definition of the word "masa" or the masses as it was used, initially by Teodoro Agoncillo, to its present derivative as culled from preliminary interviews with selfproclaimed middle class women, or the burgis (to refer to the bourgeoisie).

LARA KATRINA MENDOZA is a music scholar/sports analyst and an Instructor of the Ateneo de Manila University (ADMU). She is currently a Visiting Fellow at the Center for Popular Culture Studies at Bowling Green State University (BGSU) in Ohio, USA. (Corresponding author:Iktajonera@gmail.com) 